\author{
Bartłomiej Łuć \\ Uniwersytet Łódzki \\ bartlomiej.luc@op.pl \\ (D) https://orcid.org/0000-0003-0798-675X
}

\title{
Wpływ rozwoju infrastruktury sportowo- rekreacyjnej na turystykę sportową w Łodzi
}

\section{Streszczenie}

Niniejszy rozdział podsumowuje rozważania dotyczące łódzkiej infrastruktury sportowo-rekreacyjnej i szeroko rozumianej turystyki sportowej. Zebrane materiały źródłowe i literatura umożliwiły autorowi opisanie wpływu rozwoju bazy sportowo-rekreacyjnej w Łodzi na turystykę sportową. Główną metodę badawczą stanowiła kwerenda literatury związanej z turystyką sportową i inwentaryzacja łódzkich obiektów sportowo-rekreacyjnych. Ponadto autor zaprezentował część wyników swoich badań przeprowadzonych w trakcie Młodzieżowych Mistrzostw Świata U-20 w Piłce Nożnej Mężczyzn 2019. Nadrzędnym celem było pokazanie, w jaki sposób rozwój wspomnianej infrastruktury wpłynął na turystykę sportową w Łodzi. Analiza pozwoliła stwierdzić, że dynamiczny rozwój łódzkiej infrastruktury sportowo-rekreacyjnej wywarł istotny wpływ na wzrost znaczenia turystyki sportowej, głównie w postaci rosnącej liczby wydarzeń sportowych.

\section{Wprowadzenie}

Ostatnie kilkadziesiąt lat to okres gwałtownych zmian w Polsce, zarówno gospodarczych, społecznych, jak i związanych z rozwojem infrastruktury. Zmiany te w znacznym stopniu widoczne są także w przypadku infrastruktury sportowo-rekreacyjnej. Najczęściej przejawia się to poprzez budowę nowoczesnych stadionów piłkarskich i hal widowiskowo-sportowych. Wspomniana infrastruktura sportowo-rekreacyjna rozwinęła się także w Łodzi. Rosnąca liczba obiektów sportowo-rekreacyjnych oraz coraz lepszy stan infrastruktury umożliwia organizowanie dużej liczby wydarzeń sportowych o zasięgu ogólnopolskim i międzynarodowym. Wszystkie te czynniki wpływają na rozwój turystyki sportowej. 
W niniejszym rozdziale podjęto próbę przeanalizowania tego, jak rozwój łódzkiej infrastruktury sportowo-rekreacyjnej oddziaływał na turystykę sportową w mieście. Aspektem sprzyjającym rozwojowi tej formy aktywności turystycznej jest z pewnością korzystne położenie Łodzi i poprawiający się stan bazy noclegowej (Włodarczyk, 2016). Pod uwagę wzięto przede wszystkim wydarzenia sportowe organizowane $\mathrm{w}$ największych obiektach sportowo-rekreacyjnych, takich jak Stadion Miejski Widzewa czy hala Atlas Arena. Dokonano również inwentaryzacji i klasyfikacji wspomnianych obiektów ze względu na ich funkcjonalność i czas powstania.

Za miarę wpływu rozwoju infrastruktury sportowo-rekreacyjnej na turystykę sportową w Łodzi uznano wzrastającą systematycznie liczbę obiektów oraz rosnącą proporcjonalnie liczbę wydarzeń sportowych.

\section{Przegląd literatury}

Zależnościami pomiędzy infrastrukturą sportowo-rekreacyjną a turystyką sportową zajmowało się wielu naukowców, zarówno polskich, jak i zagranicznych, m.in. Kowalczyk (2005), Coleman i in. (2005), Hadzik (2010), Fourie i Santana-Galla (2011), Bosiacki i Śniadek (2012), Berbeka (2013) czy też Cieślikowski (2017). Kowalczyk (2005) podkreślił, że wydarzenia organizowane w obiektach sportowo-rekreacyjnych powodują rozwój wielu form turystyki miejskiej, w tym w dużym stopniu turystyki sportowej. Coleman i in. (2005) stwierdzili z kolei, że inwestycje $\mathrm{w}$ infrastrukturę sportową są czynione m.in. w celu przyciągnięcia do miast turystów. Hadzik (2010) uważał, że wydarzenia sportowe i budowane ze względu na ich organizację obiekty sportowe w znacznym stopniu zwiększają potencjał turystyczny miast. Fourie wraz z Santana-Gallego (2011) sądzili zaś, że wydarzenia organizowane $\mathrm{w}$ obiektach sportowo-rekreacyjnych przyczyniają się do przyjazdu turystów krajowych i zagranicznych. Bosiacki i Śniadek (2012) przytoczyli argument, że wydarzenia organizowane na tych obiektach mogą być kluczowym elementem strategii promocji miast. Według Berbeki (2013) obiekty sportowo-rekreacyjne są najprostszym elementem sportowym zlokalizowanym w przestrzeni miasta. Mogą one być fundamentalną częścią rekreacyjnych i sportowych obszarów miasta. Funkcjonalność oraz wpływ obiektów sportowych na turystykę sportową pokazał również Cieślikowski (2017). Podkreślił on, że obiekty takie mogą w późniejszej perspektywie czasowej stanowić produkty turystyczne.

Ponadto kilku naukowców ukazało, w jaki sposób obiekty sportowe mogą wpływać na rozwój turystyki sportowej w polskich miastach. Przykładem tego jest chociażby praca Borzyszkowskiego (2012), który zajął się analizą tego zjawiska w polskich miastach, w których odbywały się mecze podczas Mistrzostw Europy w Piłce Nożnej Mężczyzn Euro 2012. Cieślikowski i Kantyka (2015) przedstawili natomiast sytuację Katowic. Na łódzkiej infrastrukturze sportowo-rekreacyjnej i jej wpływie na turystykę w mieście skupił się Włodarczyk (2016). 
Kluczowym pojęciem stosowanym w pracy jest turystyka sportowa. Po przeanalizowaniu powstałych dotychczas definicji uznano, że najlepsza będzie ta opracowana przez Gibsona (1998). Jego zdaniem jest to podróż poza miejsce stałego zamieszkania $\mathrm{w}$ celu uczestnictwa $\mathrm{w}$ wydarzeniu sportowym $\mathrm{w}$ roli kibica lub widza oraz podróż do miejsc ściśle związanych ze sportem. W definicji tej zawarto najistotniejsze elementy kształtujące zjawisko turystyki sportowej.

Wpływ infrastruktury sportowo-rekreacyjnej na turystykę sportową zauważalny jest również w Łodzi. Większość badań naukowych związanych z tym aspektem prowadzona była $\mathrm{w}$ trakcie konkretnych wydarzeń sportowych lub też w odniesieniu do konkretnych obiektów sportowych. Niniejsze praca jest pierwszą próbą zaprezentowania ogólnego wpływu rozwijającej się infrastruktury sportowo-rekreacyjnej na turystykę sportową w Łodzi.

\section{Metodyka badań}

Podstawową metodą badawczą była kwerenda literatury dotycząca turystyki sportowej i materiałów źródłowych opracowanych przez władze miejskie, MOSiR i instytucje zarządzające danymi obiektami. Zaprezentowano również część wyników badań ankietowych przeprowadzonych w 2019 r. w trakcie Młodzieżowych Mistrzostw Świata U-20 w Piłce Nożnej Mężczyzn. Wzięło w nich udział 200 przypadkowo spotkanych obok Stadionu Widzewa kibiców bezpośrednio przed rozpoczęciem meczów. Respondentów zapytano m.in. o długość pobytu w Łodzi, obiekt noclegowy, z którego usług korzystali w czasie pobytu, czy też o ogólną ocenę organizacji turnieju. Wyniki tych badań pozwoliły w znacznym stopniu scharakteryzować ruch turystyczny związany ze sportem w trakcie trwania większego wydarzenia sportowego w Łodzi.

\section{Wyniki badań}

Kwerenda literatury i innych źródeł informacji oraz badania ankietowe okazały się kluczowe dla opracowania niniejszego rozdziału. Po przeanalizowaniu historii rozwoju łódzkiej infrastruktury sportowo-rekreacyjnej pokazano, w jakim stopniu wpłynęło to na wzrost liczby wydarzeń sportowych od kilkunastu lat organizowanych w nowo powstałych obiektach.

\section{Historia łódzkiej infrastruktury sportowo-rekreacyjnej}

Narodziny łódzkiej infrastruktury sportowej datowane są na początek XX w. Były one związane $z$ powstaniem kilku towarzystw piłkarskich wspieranych przez władze miejskie poprzez przeznaczenie terenów na inwestycje (Włodarczyk, 2016). Jednym z najbardziej charakterystycznych obiektów zbudowanych w tamtym 
czasie był Stadion Miejski ŁKS-u. Ponadto przed II wojną światową powstało kilka kompleksów kortów tenisowych oraz do uprawiania jeździectwa (ryc. 1).

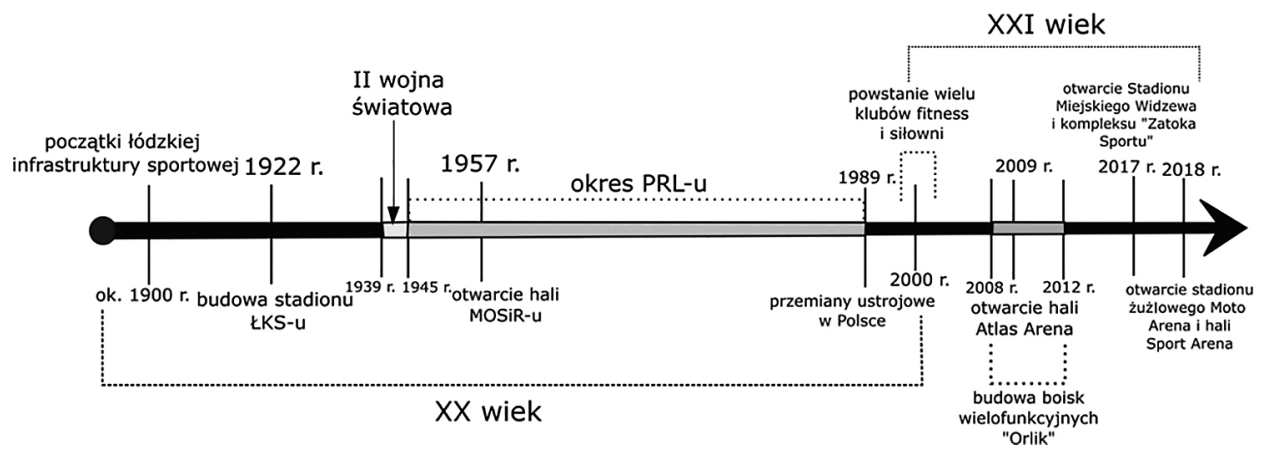

Ryc. 1. Etapy rozwoju łódzkiej infrastruktury sportowo-rekreacyjnej

Źródło: opracowanie własne.

Po wojnie do czasu przemian ustrojowych w 1989 r. w Łodzi powstawały przede wszystkim kryte pływalnie budowane przy szkołach i innych placówkach edukacyjnych. W 1957 r. zbudowano również halę widowiskowo-sportową łódzkiego MOSiR-u, która przez ponad 50 lat była jednym z najważniejszych łódzkich obiektów sportowych. W roku 1989 w Łodzi znajdowało się około 35 obiektów sportowo-rekreacyjnych (ryc. 2). Ich lokalizacja skupiona była przede wszystkim w pobliżu centrum miasta w dzielnicy Śródmieście. Duża liczba obiektów usytuowana była też w dzielnicy Widzew (ryc. 3). Niewiele obiektów wzniesiono na przedmieściach.

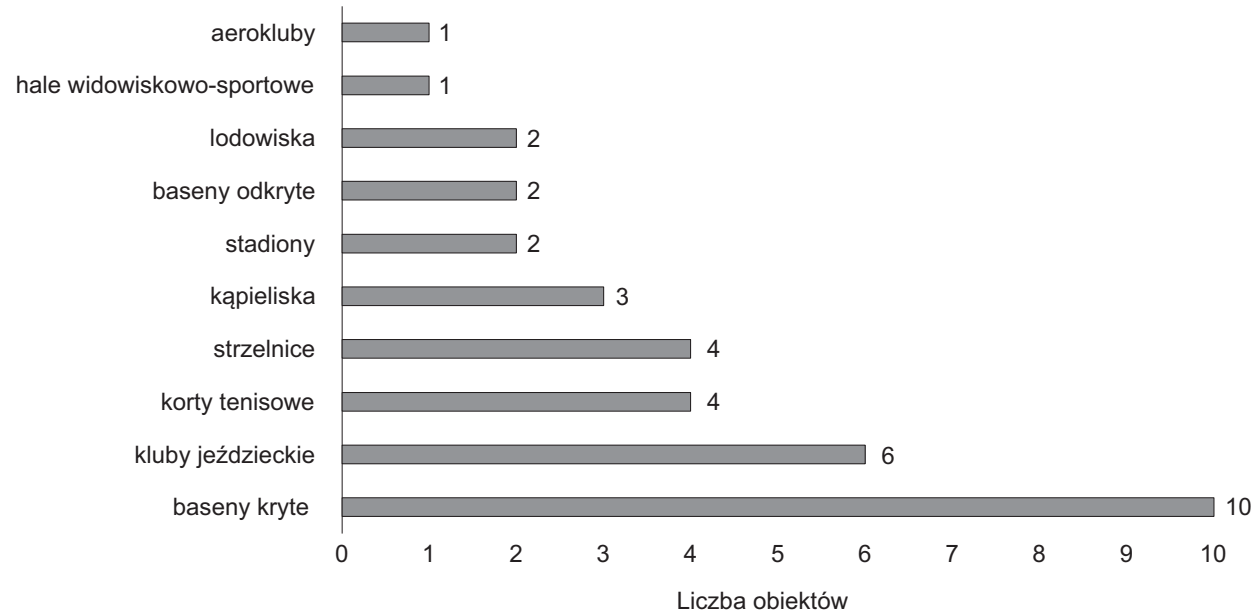

Ryc. 2. Liczba poszczególnych łódzkich obiektów sportowo-rekreacyjnych w roku 1989 Źródło: opracowanie własne na postawie http://www.mosir.lodz.pl/. 


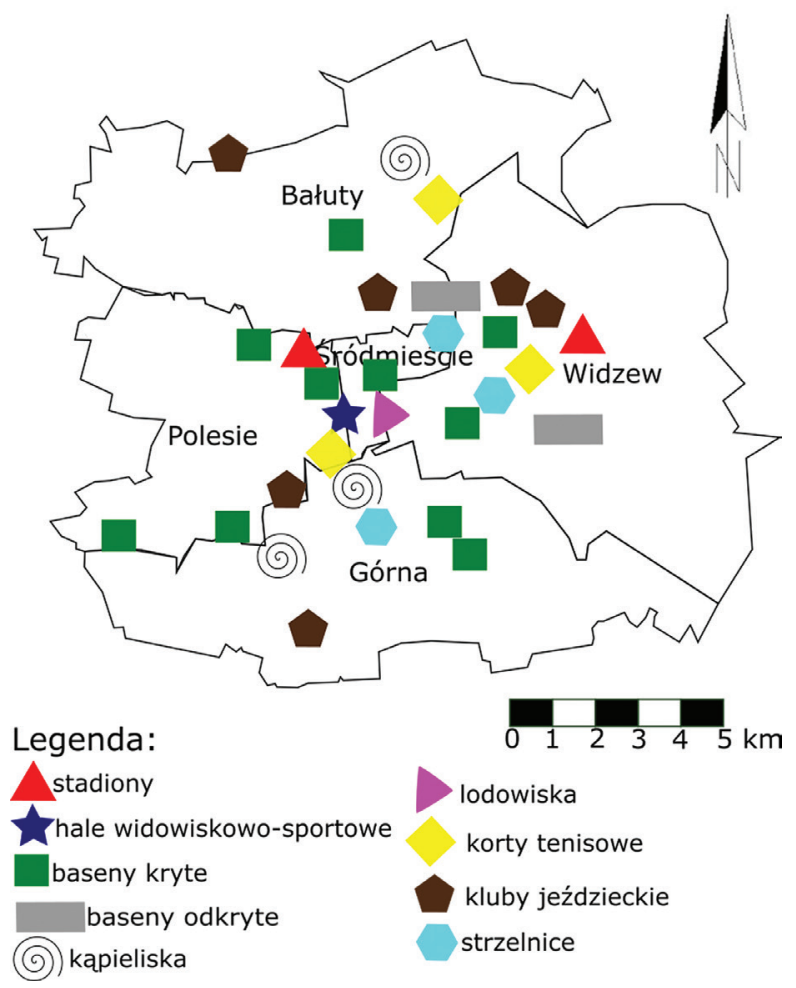

Ryc. 3. Infrastruktura sportowo-rekreacyjna w Łodzi w roku 1989 Źródło: opracowanie własne na postawie http://www.mosir.lodz.pl/.

Od momentu przemian ustrojowych nastąpił dynamiczny rozwój łódzkiej infrastruktury sportowo-rekreacyjnej. W szczególności dynamika ta widoczna jest na przestrzeni ostatnich kilkunastu lat. Na przełomie XX i XXI w. masowo powstawały siłownie i kluby fitness. Od 2008 do 2012 r. zbudowano także kilkadziesiąt boisk wielofunkcyjnych, tzw. „Orlików”. Był to rezultat rządowego programu związanego z organizacją przez Polskę i Ukrainę Mistrzostw Europy w Piłce Nożnej Mężczyzn Euro 2012 (ryc. 4). Boiska te powstawały przede wszystkim przy szkołach i placówkach edukacyjnych oraz na osiedlach mieszkaniowych.

Ostatnie lata to okres, w którym zbudowano największe łódzkie obiekty sportowo-rekreacyjne. Dużym echem odbiło się otwarcie hali widowiskowo-sportowej Atlas Arena w 2009 r. Innym okazałym obiektem jest Stadion Widzewa wzniesiony na miejscu poprzedniego przestarzałego już obiektu. Ponadto zbudowano takie obiekty, jak: stadion żużlowy Moto Arena, hala widowiskowo-sportowa Sport Arena czy Akademickie Centrum Sportowo-Dydaktyczne Politechniki Łódzkiej „Zatoka Sportu”. Na zaawansowanym etapie budowy jest stadion ŁKS-u. Nowo powstałe obiekty mogą się także pochwalić największą pojemnością spośród wszystkich łódzkich aren sportowych (tab. 1). 


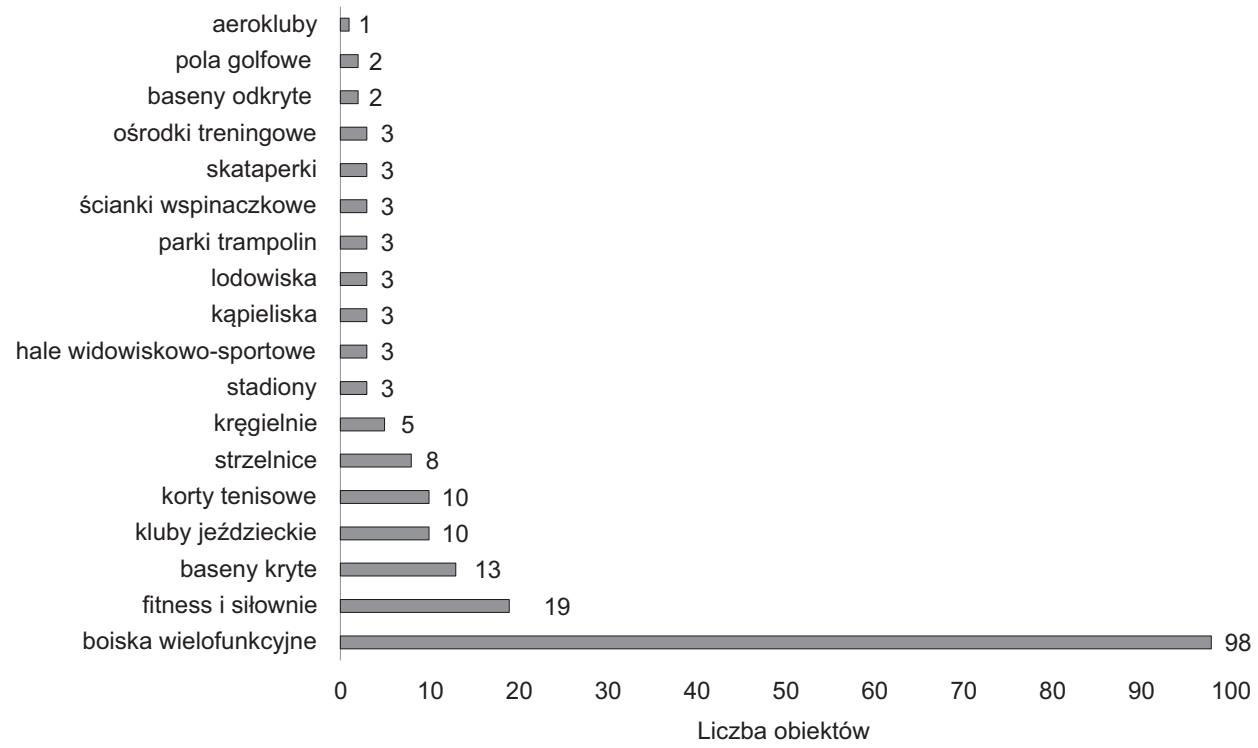

Ryc. 4. Liczba poszczególnych łódzkich obiektów sportowo-rekreacyjnych w roku 2020 Źródło: opracowanie własne na postawie http://www.mosir.lodz.pl/.

Tabela 1. Największe łódzkie obiekty sportowo-rekreacyjne - stan na 2020 r.

\begin{tabular}{lllcr}
\hline Lp. & Nazwa obiektu & $\begin{array}{c}\text { Lokalizacja } \\
\text { (dzielnica Łodzi) }\end{array}$ & Rok powstania & $\begin{array}{c}\text { Pojemność } \\
\text { (liczba miejsc } \\
\text { siedzących) }\end{array}$ \\
\hline \multicolumn{5}{c}{ Stadiony } \\
\hline 1. & Stadion Widzewa & Widzew & 2017 & 18018 \\
2. & Moto Arena & Polesie & 2018 & 10350 \\
3. & Stadion Miejski & Polesie & 2015 (w trakcie dal- & 5700 \\
\multicolumn{5}{c}{ szej rozbudowy) } \\
\hline 1. & Atlas Arena & Hale widowiskowo-sportowe & 13806 \\
2. & Hala MOSiR & Polesie & 2009 & 9010 \\
3. & Sport Arena & Polesie & 1957 & 3017 \\
\hline
\end{tabular}

Źródło: opracowanie własne na podstawie http://stadiony.net/ oraz https://makis.pl/.

Obecnie obiekty sportowo-rekreacyjne zlokalizowane są na terenie całego miasta. Ich największa koncentracja występuje w centralnych obszarach miasta. W porównaniu ze stanem infrastruktury sportowo-rekreacyjnej sprzed czasów transformacji ustrojowej widoczny jest jej rozwój na terenach zlokalizowanych w dalszej odległości od centrum i na peryferiach (ryc. 5). 


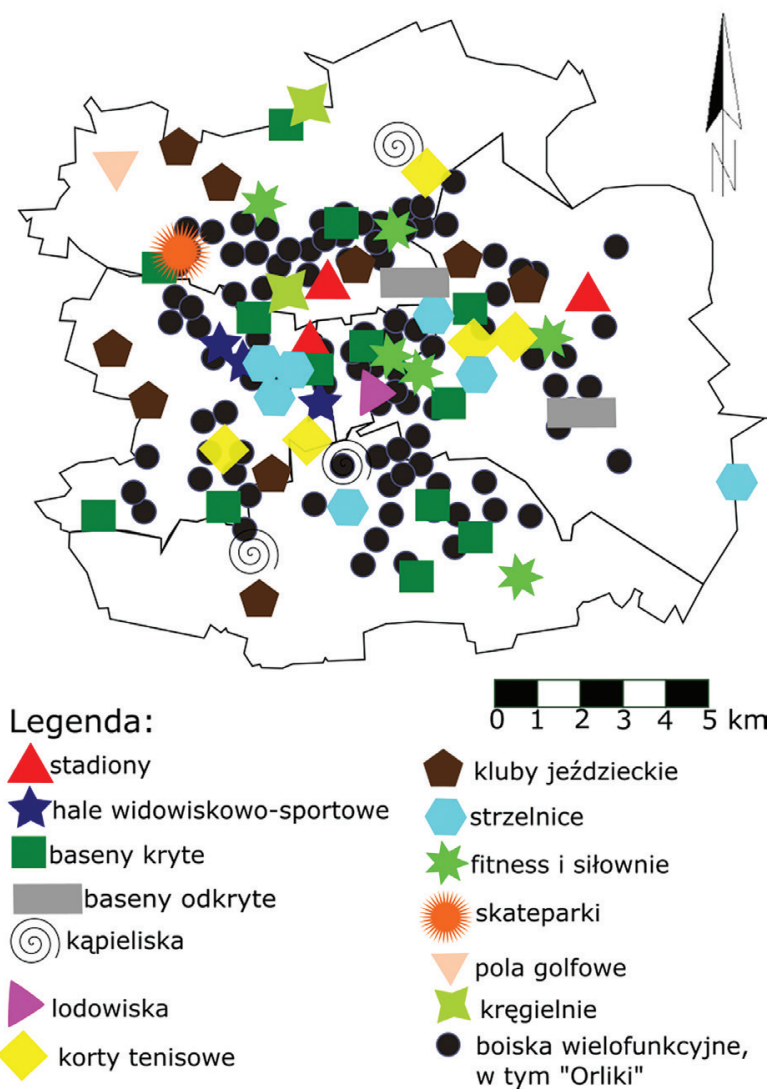

Ryc. 5. Infrastruktura sportowo-rekreacyjna w Łodzi - stan na 2020 r. Źródło: opracowanie własne na postawie http://www.mosir.lodz.pl/.

\section{Wydarzenia sportowe w Łodzi}

Rozwój łódzkiej infrastruktury sportowej w znacznym stopniu przyczynił się do wzrostu znaczenia turystyki sportowej. Ta forma turystyki rozwinęła się głównie poprzez organizowanie coraz większej liczby wydarzeń sportowych, na które przyjeżdżają przede wszystkim kibice z Polski i z zagranicy. Ważnym momentem było otwarcie hali widowiskowo-sportowej Atlas Arena oraz powstanie w kolejnych latach takich obiektów, jak np. Stadion Widzewa czy stadion Moto Arena. Wcześniej liczba wydarzeń sportowych organizowanych w Łodzi nie była zbyt okazała. Sporadycznie odbywały się jedynie mecze siatkarskiej reprezentacji Polski mężczyzn w starej hali łódzkiego MOSiR-u lub mecze piłkarskiej reprezentacji Polski na starym Stadionie Miejskim Widzewa. Od momentu otwarcia Atlas Areny odbyło się tam kilka znaczących wydarzeń sportowych o zasięgu międzynarodowym. Obiekt ten najczęściej miał okazję być „gospodarzem” imprez siatkarskich $z$ udziałem obydwu polskich reprezentacji oraz siatkarzy Skry Bełchatów. 
Dużą popularnością cieszą się również mitingi lekkoatletyczne Pedro’s Cup czy różnego rodzaju gale sztuk walki.

Na początku 2017 r. otwarto również nowy Stadion Miejski Widzewa. Jest on w głównej mierze obiektem, na którym swoje mecze rozgrywa piłkarska drużyna Widzewa Łódź, jednak miał on także okazję gościć kilka wydarzeń o zasięgu międzynarodowym. Do tej pory największym z nich były Młodzieżowe Mistrzostwa Świata U-20 w Piłce Nożnej Mężczyzn 2019.

Pierwszym większym wydarzeniem sportowym zorganizowanym w Łodzi były Mistrzostwa Europy w Koszykówce Mężczyzn 2009. W hali Atlas Arena rozegrano 9 meczów, w tym 3 mecze reprezentacji Polski. Przy okazji tego wydarzenia utworzono m.in. tzw. „strefę kibica” w centrum handlowym Manufaktura. Na czas wydarzenia uruchomiono też darmową komunikację miejską (Włodarczyk, 2016).

Kilka dni później rozpoczęły się Mistrzostwa Europy w Piłce Siatkowej Kobiet. W Łodzi wszystkie swoje mecze rozegrała reprezentacja Polski. Odbyły się tu również mecze finałowej fazy turnieju. Przy okazji organizacji turnieju na placu Dąbrowskiego stworzono „strefę kibica” wraz z Piknikiem Siatkarskim (Włodarczyk, 2016).

Obydwa wspomniane wydarzenia przyczyniły się do poprawy ogólnego wizerunku miasta wśród turystów. Atlas Arena otrzymała również status Sportowego Obiektu Roku 2009. W tym roku ponad 36\% turystów zagranicznych przyjechało do Łodzi w celu uczestnictwa w tych wydarzeniach (Tanaś, 2010).

Kolejnym istotnym wydarzeniem były zorganizowane w $2011 \mathrm{r}$. Mistrzostwa Europy w Koszykówce Kobiet. Atlas Arena gościła najważniejsze mecze turnieju, w tym mecz finałowy. Podobnie jak w przypadku poprzednich imprez utworzona została „strefa kibica” (Włodarczyk, 2016).

Bardzo ważnym wydarzeniem były też Mistrzostwa Świata w Piłce Siatkowej Mężczyzn w 2014 r. Była to jedna z największych imprez sportowych, które do tej pory odbyły się w Łodzi, reklamowana na długo przed jej rozpoczęciem. Przeprowadzono wiele działań promocyjnych polegających m.in. na intensywnym informowaniu o wydarzeniu poprzez montaż wielkoformatowych banerów, graficznej szaty pojazdów komunikacji miejskiej czy organizację mniejszych imprez poprzedzających. W trakcie turnieju w centrum handlowym Manufaktura zorganizowano „strefę kibica” (Włodarczyk, 2016). Hala Atlas Arena gościła mecze drugiej i trzeciej fazy turnieju. Swoje spotkania rozegrała tu także reprezentacja Polski. Łącznie odbyło się tutaj 13 meczów. Szacuje się, że średnia frekwencja wyniosła ponad 95\%. W trakcie turnieju Łódź odwiedziło ponad 100 tys. turystów.

Badania przeprowadzone podczas turnieju pokazały, że największa liczba przyjezdnych pochodziła z województw: łódzkiego (35\%), mazowieckiego (25\%) i wielkopolskiego (10\%). Respondenci w pięciostopniowej skali najwyżej ocenili atmosferę wydarzenia $(4,83)$ i nagłośnienie obiektu $(4,64)$. Najgorzej oceniono dostępność miejsc parkingowych $(3,68)$. Największa liczba kibiców przybyła do Łodzi samochodami osobowymi. Ankietowanym w trakcie pobytu najczęściej towarzyszyli znajomi i rodzina. Ponad $70 \%$ badanych uczestniczyło w jednym meczu, byli to więc tzw. odwiedzający jednodniowi (Sobierajska, 2015). Mimo tego lódzkie hotele odnotowały w tym czasie stosunkowo duże obłożenie pokoi 
(ryc. 6). Dla przyjezdnych miasto przygotowało również ofertę uzupełniającą w postaci zniżek za bilety wejściowe do muzeów i kilku obiektów sportowych. Niestety atrakcje te odwiedził tylko niecały $1 \%$ kibiców (ryc. 7). Turniej okazał się dla Łodzi sukcesem zarówno pod względem organizacji, jak i budowania wizerunku miasta wśród turystów (Włodarczyk, 2016).

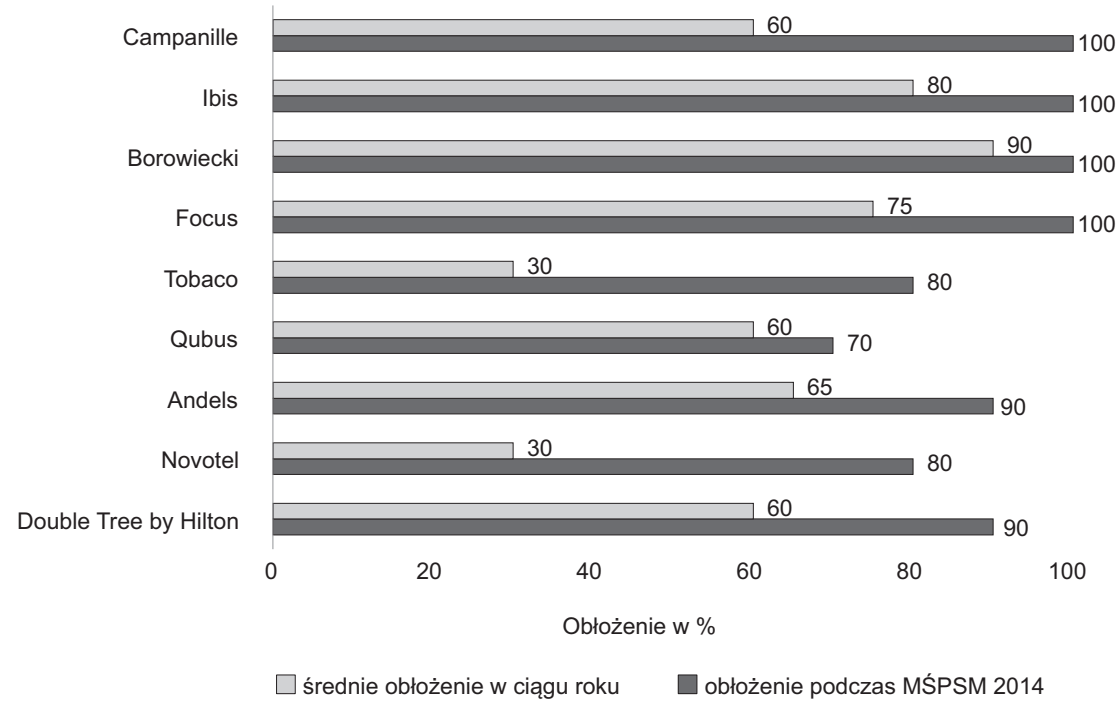

Ryc. 6. Obłożenie wybranych łódzkich hoteli w ciągu roku i w trakcie trwania MŚPSM 2014

Źródło: opracowanie własne na podstawie Włodarczyk (2016, za: www.lodz.gazeta.pl).

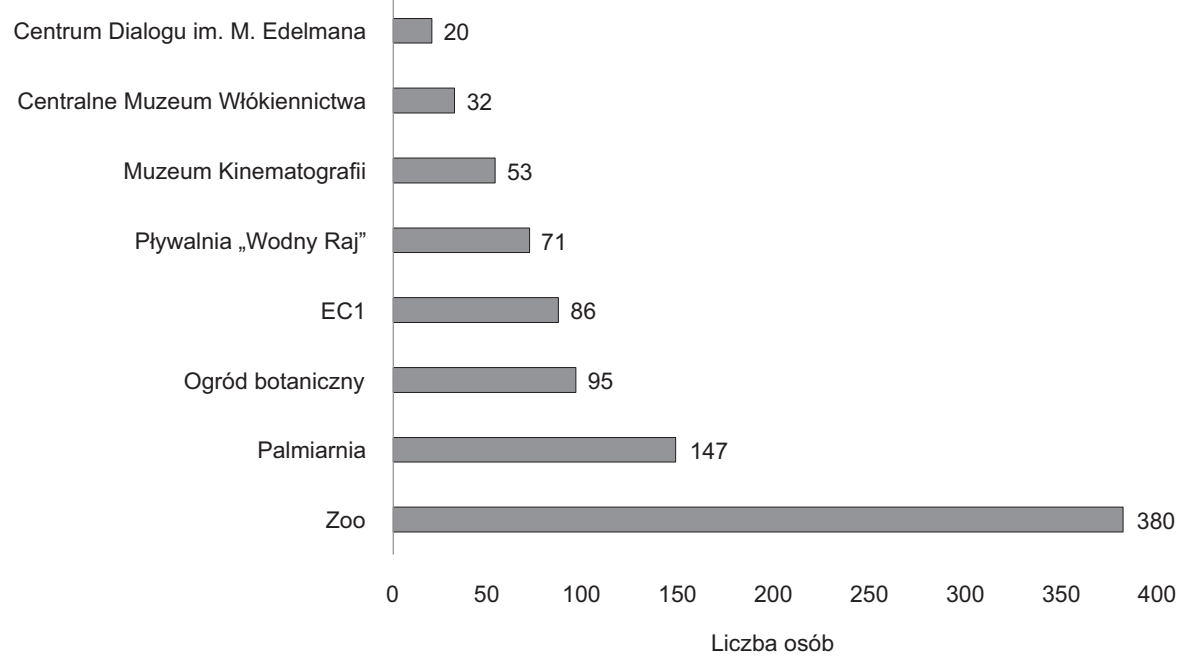

Ryc. 7. Liczba odwiedzających Łódź w wybranych obiektach w trakcie trwania MŚPSM 2014 za okazaniem biletu na mecz

Źródło: opracowanie własne na podstawie Włodarczyk (2016, za: www.lodz.gazeta.pl). 
Innym ważnym wydarzeniem sportowym zorganizowanym w Łodzi były Młodzieżowe Mistrzostwa Świata w Piłce Nożnej Mężczyzn w 2019 r. Odbyły się one na nowo powstałym Stadionie Miejskim Widzewa. W trakcie turnieju rozegrano tu 10 meczów, w tym mecze grupowe reprezentacji polski i mecz finałowy. Średnia frekwencja wyniosła ponad 10 tys. widzów, co stanowiło około $56 \%$ łącznego obłożenia. W porównaniu z opisywanymi wcześniej siatkarskimi mistrzostwami świata impreza ta cieszyła się o wiele mniejszą popularnością. Działania promocyjne również były mniej intensywne i oparte jedynie na pojedynczych banerach i folderach. W trakcie turnieju przeprowadzono badania z osobami, które przyjechały na mecz. Byli to przede wszystkim kibice z województwa łódzkiego (29\%), zaś w drugiej kolejności z województwa mazowieckiego (7\%) i kujawsko-pomorskiego (7\%).

Wśród ankietowanych około $36 \%$ to byli obywatele z innych krajów, głównie Korei Południowej i Nowej Zelandii (Łuć, 2020). Ich obecność była spowodowana jednak tym, że ich drużyny rozgrywały swoje mecze właśnie w Łodzi. W zdecydowanej większości respondenci w trakcie turnieju nocowali w łódzkich hotelach (ryc. 8). Najczęściej ich pobyt w Łodzi trwał jedynie kilka godzin. Poza oglądaniem meczu bardzo rzadko decydowali się na zwiedzanie miasta. Ponad $80 \%$ badanych docierało na mecze samochodami osobowymi.

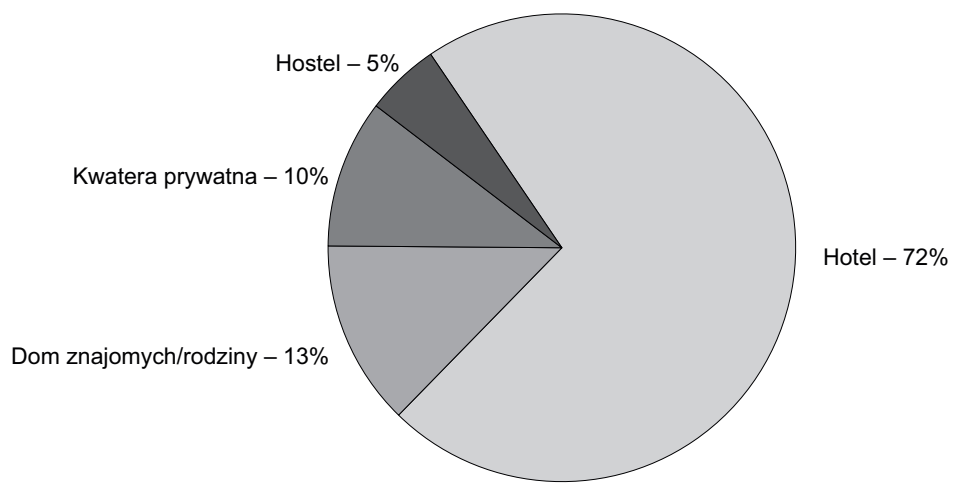

Ryc. 8. Obiekty noclegowe, w których nocowali ankietowani Źródło: opracowanie własne.

Organizację turnieju w największym odsetku ocenili dobrze (ryc. 9). Podkreślano duże zaangażowanie wolontariuszy oraz wysoki poziom infrastruktury stadionu i najbliższej okolicy. Wśród negatywnych aspektów wymieniano problemy z zaparkowaniem samochodu przed meczem oraz duże natężenie ruchu na łódzkich ulicach. W pięciostopniowej skali ocena organizacji turnieju przez Łódź oceniona została na 4,05 . Nieco lepsze oceny wskazali polscy respondenci $(4,07 \mathrm{przy}$ średniej ocenie zagranicznych badanych 3,25) (Łuć, 2020). W przeciwieństwie do innych wspomnianych wydarzeń sportowych w Łodzi Młodzieżowe Mistrzostwa Świata U-20 w Piłce Nożnej nie do końca okazały się sukcesem organizacyjnym. Władze miejskie stosunkowo słabo promowały ten turniej, nie prowadziły tak dynamicznych działań jak chociażby w przypadku siatkarskich mistrzostw świata. 
W trakcie turnieju jedynym miejscem poza stadionem, w którym znajdowały się jakiekolwiek motywy związane z imprezą, była ulica Piotrkowska. Ponadto niewielu kibiców zwiedzało atrakcje turystyczne Łodzi i korzystało z jakichkolwiek usług turystycznych. Wszystko to sprawiło, że organizacja turnieju nie mogła poprawić wizerunku miasta w świadomości turystów i pomóc w skutecznej promocji turystycznej.

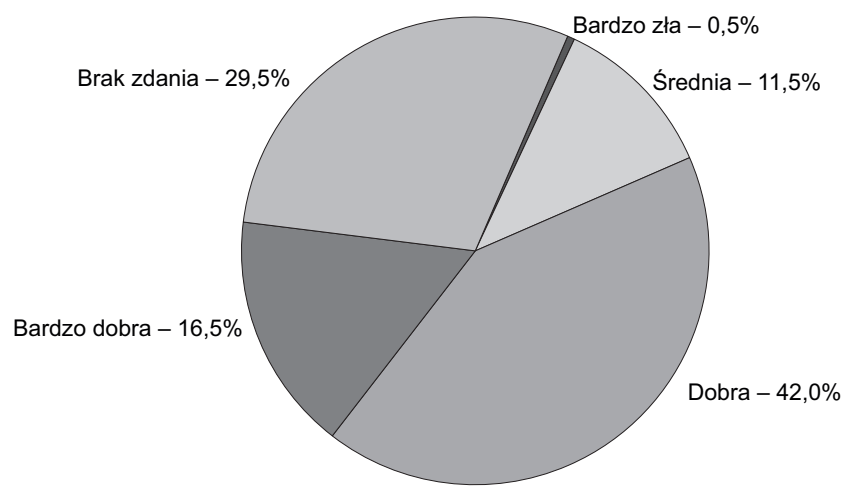

Ryc. 9. Organizacja Młodzieżowych Mistrzostw Świata U-20 w Łodzi w opinii ankietowanych Źródło: opracowanie własne.

\section{Zakończenie}

Kwerenda literatury i badania ankietowe wykazały, że rozwijająca się infrastruktura sportowo-rekreacyjna może stanowić dużą szansę dla rozwoju turystyki sportowej. Powstające obiekty sportowo-rekreacyjne są miejscami, w których mogą odbywać się wydarzenia sportowe przyciągające turystów z innych miast i krajów. W przypadku Łodzi rosnąca liczba wydarzeń sportowych w nowo powstałych obiektach sportowych nie zawsze jednak przekłada się na rozwój turystyki sportowej. Pod tym względem sukcesem zakończyła się większość wydarzeń zorganizowanych w hali Atlas Arena, zwłaszcza Mistrzostwa Świata w Piłce Siatkowej Mężczyzn 2014. Były jednak i takie wydarzenia, jak Młodzieżowe Mistrzostwa Świata U-20 w Piłce Nożnej Mężczyzn 2019, które w niewielkim stopniu wpłynęły na turystykę sportową i nie przyczyniły się do poprawy wizerunku miasta wśród turystów. Mimo wszystko budowa nowoczesnych obiektów sportowych to duża szansa dla każdego miasta na poprawę wizerunku i przyciągnięcia turystów uprawiających nie tylko turystykę sportową, ale też inne formy turystyki miejskiej.

\section{Literatura}

Berbeka J. (2013). Ewolucja form i roli obiektów sportowych w turystyce miejskiej. Studia Ekonomiczne, Uniwersytet Ekonomiczny w Katowicach, 147: 9-20.

Borzyszkowski J. (2012). Mistrzostwa Europy w Piłce Nożnej UEFA EURO 2012 a turystyka w Polsce - wstępna ocena. Turystyka Kulturowa, 9: 55-68. 
Bosiacki S., Śniadek J. (2012). Sport jako element strategii promocji miasta. Przedsiębiorczość i Zarządzanie, 13, 10: 13-23.

Cieślikowski K. (2017). Nowoczesne obiekty sportowe jako atrakcyjne produkty turystyczne regionu. Przedsiębiorczość i Zarządzanie, 18, 8, 3: 347-361.

Cieślikowski K., Kantyka J. (2015). Wykorzystanie wielkich wydarzeń w promocji miasta - na przykładzie Katowic. Zeszyty Naukowe Uczelni Vistula, 40: 29-41.

Coleman R., Gratton C., Shibli S. (2005). The economics of sport tourism at major sport events. W: J. Higham (red.), Sport tourism destinations: issues, opportunities and analysis. Elsevier Butterworth Heinemann, Oxford, s. 233-247.

Fourie J., Santana-Gallego M. (2011). The impact of mega-sport events on tourist arrivals. Tourism Management, 32(6): 1364-1370.

Gazeta.pl (https://www.gazeta.pl/0,0.html; dostęp: 6.12.2020).

Gibson H. (1998). Active Sport Tourism, Who Participe? Leusier Studies, 17(2): 155-179.

Hadzik A. (2010). Infrastruktura wielkich wydarzeń sportowych jako element współczesnego potencjału turystycznego w Polsce. Zeszyty Naukowe Uniwersytetu Szczecińskiego, Ekonomiczne Problemy Usług, 52: 465-474.

Kowalczyk A. (2005). Nowe formy turystyki miejskiej. Prace i Studia Geograficzne, 35: 155-197.

Łuć B. (2020). Fanoturyści podczas Młodzieżowych Mistrzostw Świata U-20 w Piłce Nożnej Mężczyzn FIFA 2019 w Łodzi. Turystyka Kulturowa, 2: 24-40.

MAKiS Miejska Arena Kultury i Sportu (https://makis.pl; dostęp: 4.12.2020).

MOSiR Miejski Ośrodek Sportu i Rekreacji (http://www.mosir.lodz.pl; dostęp: 5.12.2020).

Sobierajska K. (2015). Wpływ wielkich wydarzeń sportowych na turystykę w Łodzi - przykład Mistrzostw Świata w Piłce Siatkowej Mężczyzn 2014. Praca magisterska napisana pod kier. prof. B. Włodarczyka w Instytucie Geografii Miast i Turyzmu UŁ.

Stadiony Net (https://stadiony.net.pl; dostęp: 6.12.2020).

Tanaś S. (2010). Charakterystyka uczestników ruchu turystycznego. W: S. Liszewski (red.), Ruch turystyczny w Łodzi i województwie łódzkim w 2009 roku. Oficyna Wydawniczo-Reklamowa SAGALARA, Łódź, s. 79-87.

Włodarczyk B. (2016). Łódź jako arena wielkich wydarzeń sportowych - wybrane przykłady. Turyzm, 26(1): 51-62.

\section{Impact of the development of sports and recreational infrastructure on sports tourism in Łódź}

This article is a summary of the considerations concerning the sports and recreation infrastructure in Łódź and widely understood sports tourism. The collected source materials and literature allowed the author to describe the impact of the development of sports and recreation facilities in Łódź on sports tourism. The main research method was a query of literature related to sports tourism and an inventory of sports and recreation facilities in Łódź. In addition, the author presented some of the results of his research carried out during the U-20 Men's Football World Cup 2019. The overriding goal was to show how the development of the aforementioned infrastructure had an impact on sports tourism in Łódź. The conducted analysis made it possible to conclude that the dynamic development of the sports and recreational infrastructure in Łódź had a significant impact on the increase in the importance of sports tourism, mainly in the form of an increasing number of sports events. 